\title{
Stage Design Characteristic for National Cultural Event in Jakarta
}

\author{
Sri Rachmayanti Imam Santosa Acep Iwan Saidi Andryanto Rikrik Kusmara \\ Faculty of Fine Art and Design, Institut Teknologi Bandung (ITB), Jl. Ganesa no.10, Bandung 40132 - Indonesia
}

\begin{abstract}
Ariah is an art performance prepared for National cultural event in Jakarta. Ariah has Indonesia traditional value. The value has to be preserved as cultural asset. An attractive performance that has traditional value, also need a good stage design. This research is to discuss Ariah's stage design characteristic and all the effort to present traditional value. The problem statement of these research is to know Ariah performance collaborating traditional content and also applied advance technology in the show. The collaboration from some different field, such as: stage design, lighting design, costume design, sound system, and special effect. The research using a qualitative method with interdisciplinary approaches by collecting literature data, from theater, art, culture and design. The purpose of this research is to identify what is Ariah's design concept. At the other hand, this research purpose is to show how important of other supporting elements to build a good performance.In discussing Ariah stage design, using Charles Jencks theory, double coding. The expected outcome of this research besides design concept, also to understand the combination of traditional and advance technology in Ariah performance.
\end{abstract}

Keywords: Ariah, performance, design concept, traditional value

DOI: $10.7176 / \mathrm{ADS} / 84-02$

Publication date:August $31^{\text {st }} 2020$

\section{Introduction}

Theatrical performance is an art work, though theatre audiences are allowed to see an art that not only provides knowledge, lecture, and enlightenment, but it also presents pleasure and satisfaction. A theatre is the most objective art, because it also gives the audience physical and emotional experiences both directly and indirectly. Audience also can have sensory and spiritual experience through the strong feeling of the characters from the theatre player.

A theatre performance which consists of culture, has another function to introduce and promote a tradition to the younger generation. The younger generation are very skillful with technology. Modern performances are easily accessed using gadgets and social media. It was a challenge to make the younger generation become interested in cultural performances. Performances with the applications of the latest technology will be easier to access and to be accepted by the younger generation who are really familiar with technology.

Peter Brook stated that a living theatre performance is a performance that is able to make something that is invisible become visible (Sugiharto, 2015). The usage of stage design, lighting, video mapping, and special effect as a technology factor in a theatre performance. The stage design also used to create time and space that was expected from the storyline. Besides technical problems that are related with technology, a theatre performance also becomes a show that mixed different kinds of art. In a theatre performance, every kind of art was shown. In a theatre production, many different kinds of artists were involved, starting from actor, actress, painter for decoration and stage properties, costume designer, make-up artist, lighting man, musician, and sound man (Satoto, 2016).

One of theatre performances that includes a mixed cultural tradition with the usage of technology is Ariah. This research is limited to discuss only Musical Theatre Ariah. Ariah is a Musical Theatre by Atillah Suryajaya as producer and Jay Subiyakto as the art director. The Ariah Musical Performance is very unique because it was held in a national cultural event, in celebrating the 486 years anniversary of Jakarta city. The colossal musical theatre performance of Ariah placed in the court of Monumen Nasional Jakarta using the outdoor stage, with a background of Monumen Nasional (MoNas). The stage was special because it was a huge stage in order to adjust the size of MoNas as stage background. The stage design categorized is a non-realis. In non-realis performance, visual perception of audiences took an important part. It is all based on the experiences that creates imagination and visual perception. Visual perception is a conclusion made by combining all information collected by our five senses (Azif, 2017).

\section{Methods}

The method applied in this research is interdisciplinary with cultural studies approach. Data collection methods are from literature sources about theatre, art, and culture. This method emphasizes in literature studies and observation of research objects. Ariah musical performance has two aspects, tradition and contemporary. Double coding theory from Charles Jencks is the supporting theory in discussing tradition and contemporary art. The theory stated that past tradition and diverse culture should be gestured in order to provide freedom for the future. 
Imagination, symbol, fiction and decoration should be respected and reprocessed (Jencks, 1986).

\section{Result and Disscussions}

Ariah was taken from a Betawi folklore, about the persistence and resilience woman named Ariah or known as Mariam. The story of Ariah adapted from a folklore named "Si Manis Jembatan Ancol" which have been retell for many years from a generation to generation. The striving journey of Ariah in fighting arbitrariness combined with her journey in finding her true love become the main story.

Ariah's beauty makes three men fight for her love, they are Tuan Mandor who already has a wife, Oey Tambah Sia who is a skipper, and also a young Betawi man who is a fighting master (jago silat) named Juki. Juki is the one who also taught Ariah fighting skills for her defense. Ariah's story is also a story of a struggle to keep dignity in the moral crisis during Dutch colonial era. This story was inspired from a history of the Tambun's farmers rebellion that happened in 1869.

Name Ariah in Greek means holy, even in Italy means melodious and also air. Meanwhile in Jakarta's legend, she is known as a woman who lived in the 1860's whose fight for her integrity and believe. She even became a symbol of fighting for repression and betrayal from her own nation (Subiyakto, 2013).

Ariah's story contains different kinds of meanings that break boundaries of space and time. Her struggle to not surrender, not stand by her fate. Also her courage to fight the oppression by the rulers that happened at that time was very related to space and time in the present (Soeryadjaya, 2013).

Ariah's musical stage was Jay Subiyakto's design. He create an unusual stage arrangement, geometric shape with many inclined planes. This stage is the largest outdoor stage in theatrical performance history in Indonesia. The dimensions of the stage are 72 meters long, 48 meters wide and 10 meters high. The height is also divided into 3 layers, each are: 3 meters, 7 meters and 10 meters. The different heights are divided in 3 parts, inspiring from the National Monument concepts. Has 3 parts: head, body and legs.

The existence of the National Monument is a sign of the dignity of a nation in honor of the harmony, balance and authority of a diverse nation. Monas, adapting the shape of a "lingga - yoni". The location of Monas is marked as zero point of Jakarta, which was initiated by the first President of the Republic of Indonesia, Ir. Sukarno. This monument is full of meaning and symbolization, it tells the story of struggle, passion, sacrifice and glory. The head is formed as a golden flame that never goes out, together with a kneeling woman honoring the State Palace.

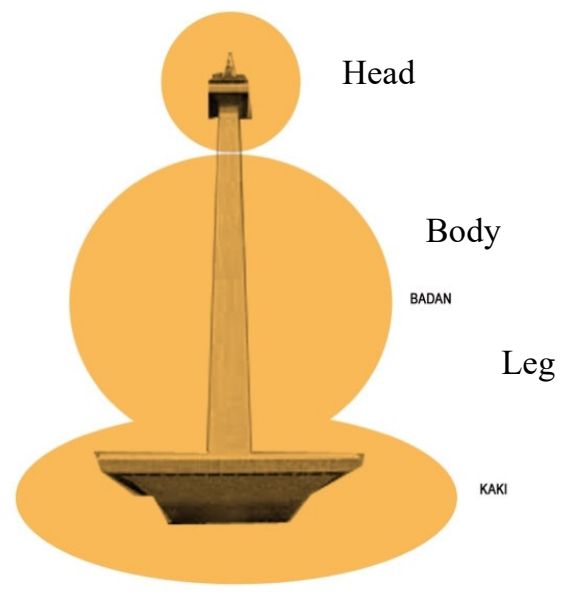

The middle part or the body, symbolizes a lingga/ phallus (masculine) and the legs or cup become a symbol of yoni (feminine) both of it, represents harmony and balance. The Ariah's performance with National Monument as the background has full of meaning and symbols. The difficulties in designing the stage need to be interpreted and balancing between proportions of form, scale and interpretation (Subiyakto, 2013). 


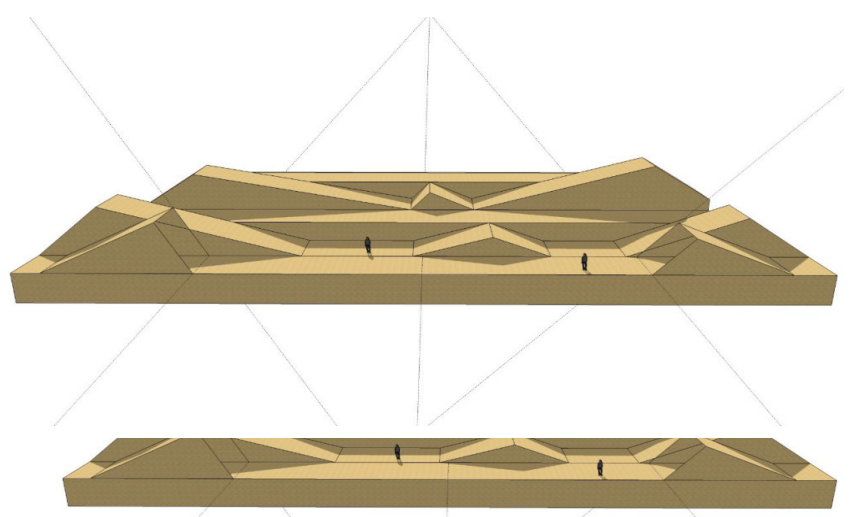

Figure 2. Ariah's Stage Model

Source: Subiyakto, 2013

The inclined planes of the National Monument become a harmony with Ariah's outdoor stage. The stage also divided into three parts, namely the head, body and legs. The length of the stage is 72 meters to maintain a whole proportion of National Monument.

Ariah's stage performance was made of a slope of 15, 20 and 35 degrees towards the audience. The stage gives the impression of depth to the stage. Spotlight shows and video mapping on an open stage, Monas itself in the center position. This happens to unite the stage so that it becomes one part of the video mapping projection. Monas pole also shoot for video mapping background. The placement of the video mapping should consider the position and angle of the projector and fireworks (because it is an outdoor stage concept, made to be watched from afar).

In some scenes from the Ariah musical theatre, the design is supported with pyrotechnics and fireworks. (fire bursts and fireworks). The fireworks show is part of the Ariah art performance stage attraction. Spotlight shows, lasers and video mapping made by Jay Subiyakto's grand stage look like a colossal, magnificent and spectacular show.

The uniqueness of open stage performance is not using the typical stage properties, like solid things, furnitures, and other things, because small properties are not suitable and appropriate for the huge stage. The properties are made together with the musical supports which consists of 250 people. Dancers and performers equipped with costumes that fit with their characters. The principles of players' structure or property used on the big stage Ariah are as follows; must have large dimensions, dispersing blocking arrangements, wide scale dance choreography. For instance, in the mask dance round, the scale and proportion of the mask properties carried by the dancers should be considered, the arrangement of costume colors and lighting colors, and the widen blocking of movements. Mask dance in Betawi culture was originally a ceremony to reject reinforcements (Nurhidayat, 2018). The mask itself is a symbol of one's character. One person can have several masks on. Betawi mask dance has 3 versions of masks which are distinguished in color, to differentiate each character. White mask for good and soft character. Masks with pink color are characterized as flirtatious women. The red mask represents the male character.

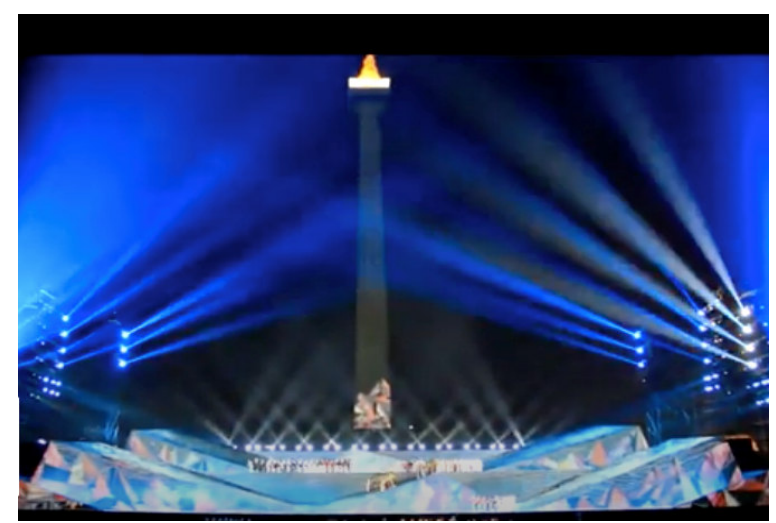

Figure 3. Monas with Video Mapping Source: Rahayu, 2013 
According to Citra Subiyakto, as the costume designer of Ariah's musical theatre, the execution of a musical theater must be visually imagined. The considerations in planning should be able to answer the questions, how the show can please the eyes of the audience, who saw it from a distance.

This needs to be considered because Ariah's musical theatre performance is not supported by the close-up screen display. The planner should be able to represent the character of the actor by giving a visual appearance that the audience can be imagined. Mostly Ariah's wardrobe are inspired from Betawi heritage costume, kebaya for woman and pangsi for man.

An open stage design must be friendly with timing, lighting and space. In making a strategic planning of a large outdoor stage such as the Monas court, stage layout design using video mapping is the solution. The stage can change color and atmosphere instantly by projecting a visual or color atmosphere by firing on the surface of the stage. As shown in Figure 3, the National Monument has patterns and colors that are in line with the stage design.

The costume designer should be able to customize the costume of the dancers or performers with the strong stage lighting. Because the strong lighting will make a difference in the color of the clothes. It is important to consider what the scene is about, what kind of atmosphere you want to present, and then find suitable solutions to the problems (Subiyakto. C, 2017).

Furthermore, the costume designer also needs to consider performers theme or character and the color that suits for every part. Their works will affected to the stage, especially colors. Not only nice the performer's costume must be representing Betawi culture. So the colors and accessories used by dancers are important. It have to be outstanding so that they will look stunning from the audience seats. For example, in one mask dance scene, the hand property is the mask itself. The size of the mask is larger than the actual scale. A mask represents the symbolic object of a character. Symbol is an arbitrary and conventional sign. In other words, a symbol is a sign that is related with the object and determined by a set of common rules (Budiman, 2003: 32).

Sometimes a person wears different kinds of masks in their life. Like the character played by the landlord. On one side wearing a helper mask and on the other side wearing a bad character mask. The Betawi mask has its own color and symbol, a white color called a banner, expressing the symbol of female's sensitivity, with gentle movements played by dancers. The pink mask is a symbol of a flirty woman. While the red mask becomes a symbol of arrogance and strength. In the past, Betawi masks were often played at a traditional party, and are believed to be able to reject reinforcements (Nurhidayat, 2018). Betawi mask dance had the influence of Sundanese and Chinese culture.

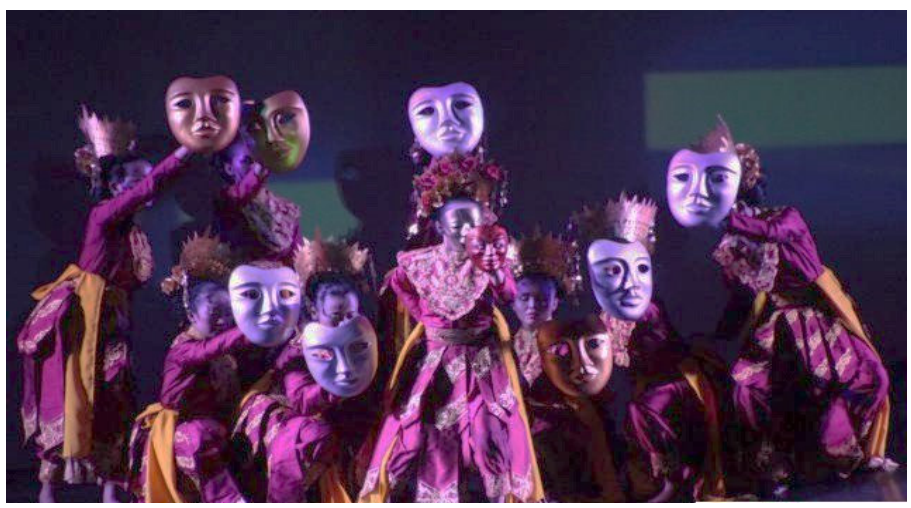

Figure 4. Topeng Dance in Ariah source: merdeka.com, 2013

Ariah's musical theatre performance made a very outstanding costume in presenting an antagonistic character in order to get recognized easily by the audience even though the audience's position is quite far from the stage, in overcoming this problem, high hat property, a very long robe is used by the character named Oey Tambah Sia (a rich man and has a lot of bodyguards). Oey Tambah Sia's costumes were adopted from Chinese skipper's costumes, emphasizing on frayed hats and long robes. The appearance of Oey Tambah Sia as an antagonist figure, was accompanied by a procession of troops that pushed the dragon-shaped ornament. 


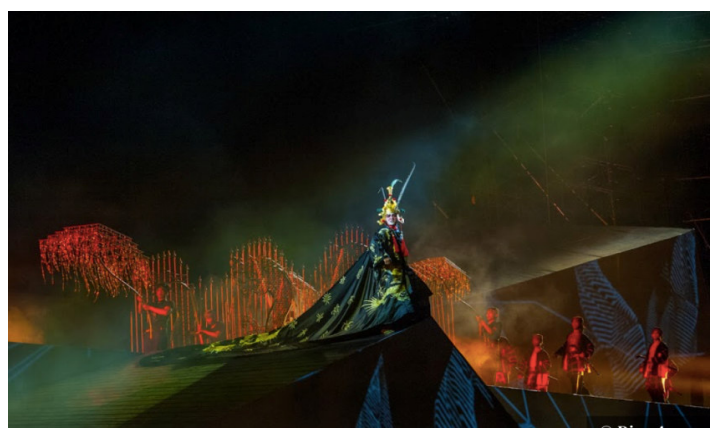

Figure 5. Costume of Oey Tambah Sia

Source: Anugrah, 2013

Ariah's musical theatre open stage concept design is a theater stage with a geometric minimalist concept. The Ariah stage consists of 3 layers with almost symmetrical shapes with such tilt angles, carrying the concept of a minimalist stage design with geometrical shapes. It is called geometric because the shape of the stage consists of several geometric shapes like squares, triangles, as well as symmetrical and measurable. It happens because according to the opinion of Dave Robinson, that no one really knows what the label of postmodernism means, it might only be a nickname to refer to a set of attitudes, values, beliefs and feelings about what the actual meaning of life at the end of the 20th century. If such an opinion is adopted, that postmodernism is a condition of contemporary culture, then all cultural products that were born in the period after the end of the 20th century cannot be separated from those called postmodernism (Sugiharto, 2015; 203).

Hurstfield emphasized that post-modern theater performances are non-narrative, and non-representational theater in which various forms, types and traditional practices have been abandoned (Sugiharto, 2015; 204). Hurstfield's opinion above is not in line with Ariah musical theatre performance, because the aspects that related to traditional values are not left behind, but still maintained

\section{Conclution}

Ariah musical theatre performance, highlighted the contemporary elements but also raised Betawi traditional culture. Contemporary elements are found in: colossal stage layout in geometric shape, lighting with video mapping projection support on the stage surface and National Monument, also in the use of special effects in the form of smoke, fireworks and fire bursts (pyrotechnics effect). Supporting elements such as background music, costumes, accessories, stage properties using Betawi traditional culture. Orchestra music, playing the rhythm of classical Betawi music. The songs that played were also adaptations from traditional Betawi songs. Dancers and performers' costumes are adapted from Betawi cultural costumes. Female dancers wear linen and kebaya. While the male dancer wears a pangsi shirt and sarong, also a peci on the head of the male main cast, Juki. The dialogue and lyrics of the songs in this show using the Betawi dialect and rhymes.

Traditional value applied in terms of; content of folklore, costume design, accompaniment of musical design, dialogue and dialect of the performers who carry Betawi cultural traditions. The combination of traditional content with contemporary appearance is double coding because traditional culture combined with contemporary ones. A contemporary look supported by technology such as; video mapping in the planning stage, lighting to support the atmosphere, as well as the effects of the pyrotechnics. The utilization of technology in the Ariah show succeeded in making the Ariah show appear contemporary, majestic and colossal.

Betawi cultural traditions mixed with technology in the technical part. The stage designed to honor and elevate the National Monument (Monas) in Jakarta national cultural event.

\section{References}

Azif, Farah, (2017), Teori Visual. Retrieved on 24 October 2019, from URL https://www.academia.edu/11408387/Teori Visual

Jencks, C. (1986). 'What is Postmodernism', London, Routledge, Taylor \& Francis Group.

Satoto, S. (2016). 'Analisi Drama \& Teater'.Yogyakarta, Penerbit Ombak.

Soeryadjaya, A. (2013). 'Ariah, Musikal Tari Kolosal'.Jakarta: Buku Program Produksi Global III L

Subiyakto, C. (2017).'Body, Space and Narrative'. Jakarta: In Talk Seminar with HDI

Subiyakto, J. (2017). 'Body, Space and Narrative'. Jakarta: In Talk Seminar with HDI

Subiyakto, J. (2013). 'Ariah, Musikal Tari Kolosal'. Jakarta: Buku Program Produksi Global III L

Sugiharto, B. (2015). Untuk Apa Seni?. Bandung: Pustaka Matahari

Nurhidayat, D. (2018), Topeng Betawi Menolak Bala, Minggu 9 September 2018, Media Indonesia E-paper. Diunduh pada tanggal 8 Juni 2020.

Budiman (2003: 32). Budiman, Kris, 1999. Kosa Kata Semiotika. Yogyakarta: LKIS 